\title{
Quality Status of Nectar Preparation from Fresh and Stored Pulp of Plum cv. Satluj Purple
}

\author{
S.S. Kundu*, R.K. Sharma and R.K. Goyal \\ Department of Horticulture, CCS Haryana Agricultural University, \\ Hisar- 125 004, Haryana, India \\ *Corresponding author
}

\begin{tabular}{|c|c|}
\hline & A B S T R A C T \\
\hline & \multirow{6}{*}{$\begin{array}{l}\text { Present study to evaluate quality of nectar preparations from fresh and stored pulp of Plum } \\
\text { fruits was carried out during } 2013-14 \text { in the laboratory of Department of Horticulture, CCS } \\
\text { HAU, Hisar, Haryana. Nectar prepared from fresh as well as from stored pulp at } \\
\text { refrigerated }\left(6 \pm 2^{\circ} \mathrm{C}\right) \text {, frozen }\left(-10 \pm 5^{\circ} \mathrm{C}\right) \text { and ambient temperature after two and four months } \\
\text { of storage was filled in glass bottles of } 200 \mathrm{ml} \text { capacity, sealed, pasteurized as per FPO } \\
\text { specifications and stored at room temperature. Quality of nectar preparation during four } \\
\text { months of storage was assessed for physico-chemical and organoleptic parameters at } 15 \\
\text { day intervals. Total soluble solids increased with the increase in storage period whereas } \\
\text { acid content remained unchanged. No variation in TSS and acid contents was observed in } \\
\text { nectar prepared from fresh and stored pulps, whereas their ratio increased significantly } \\
\text { with the increase in storage period and was found maximum in nectar prepared from pulp } \\
\text { stored at frozen temperature for two months. The reducing and total sugars increased, } \\
\text { while non-reducing sugar decreased significantly during storage. However, no significant } \\
\text { variation in total, reducing and non-reducing sugars was observed in nectar prepared from } \\
\text { fresh and stored pulps. Nectar prepared from fresh and stored pulps remained consumer } \\
\text { acceptable up to four months of storage. However, nectar prepared from the fresh as well } \\
\text { as pulp stored for two months at frozen temperature attained maximum acceptability. }\end{array}$} \\
\hline & \\
\hline $\begin{array}{l}\text { Plum, Pulp, } \\
\text { Nectar, Storage, } \\
\text { Quality, Sutlej } \\
\text { Purple. }\end{array}$ & \\
\hline Article Info & \\
\hline $\begin{array}{l}\text { Accepted: } \\
\text { 23 May } 2017 \\
\text { Available Online: } \\
\text { 10 June } 2017\end{array}$ & \\
\hline & \\
\hline
\end{tabular}

\section{Introduction}

Plum, a member of genus Prunus, belongs to the family Rosaceae and subfamily Prunoideae. Plum has been cultivated since prehistoric times, perhaps longer than any other fruit except apple (Anonymous, 2004). It was introduced in India as early as in 1870. In India, it occupies an area of 24601 hectares with an annual production of 199241 tonnes (Anonymous, 2011). Among temperate fruits, plum is unique as it can be grown successfully under varying climatic conditions (temperate high hills to subtropical plains). The fruits cannot be stored for a longer period at ambient room temperature and more over the storage of fresh plum is a tedious, time consuming and costly process. It compels the farmers to sell their produce at low price and resulting in market glut and increased post-harvest losses. Even at low temperature $\left(1^{\circ} \mathrm{C}\right)$, the Japanese plum can only be stored for 3 to 5 weeks (Navarro et al., 2005), but at ambient room temperature, its fruit cannot be stored for more than 4 days, which increases the post-harvest losses. 
These losses can be reduced by developing different value added products from fresh as well as stored pulp etc. In the present era, there is a drastic change in the life style and eating habits of the population. People have an attraction toward value added products and there is a great demand of jam, nectar, RTS, etc.

Although the literature reveals ample work (Durrani et al., 2010; Jain et al., 2011; Sakhale et al., 2012) on storage of fruits pulp but the information on the plum pulp preservation and preparation of RTSbeverage, squash, nectar, jam, jelly, etc. from stored pulp is rather scanty. Gothwal et al., (1998) found the three commercially important varieties of plum viz., Santa Rosa, Mariposa and Early Transparent Gage acceptable for the preparation and storage of pulp, squash, nectar, jam and ready to serve for a period of nine months at room temperature $\left(13\right.$ to $\left.42^{\circ} \mathrm{C}\right)$. The objective of present investigation was to evaluate the quality status of nectar preparation from fresh and stored pulp of plum cv. Satluj Purple.

\section{Materials and Methods}

The present study to evaluate quality of nectar preparations from fresh and stored pulp of Plum fruits was carried out during 2013-14 in the laboratory of Department of Horticulture, CCS HAU, Hisar, Haryana. Nectar prepared from fresh as well as from stored pulp at refrigerated $\left(6 \pm 2^{\circ} \mathrm{C}\right)$, frozen $\left(-10 \pm 5^{\circ} \mathrm{C}\right)$ and ambient temperature after two and four months of storage was filled in glass bottles of $200 \mathrm{ml}$ capacity, sealed, pasteurized as per FPO specifications and stored at room temperature. The treatments were replicated four times under completely randomized design. The quality of nectar preparation was analyzed at 15 days interval up to 4 month of storage for physico-chemical and organoleptic parameters viz., TSS (\%), acidity (\%), TSS to acid ratio, total sugars (\%), reducing sugars $(\%)$, non-reducing sugars (\%), browning (NEB) and organoleptic rating. The total soluble solids of nectar samples were determined at room temperature by Digital Refractometer, acidity was determined as per the method suggested by AOAC (1990), the ratio of total soluble solids to acid was obtained by dividing the total soluble solid with total acid, sugars were determined by using the potassium ferricyanide method of Hulme and Narain (1931) and organoleptic rating was judged by following the 9 points hedonic rating scale as described by Rangana (1977). The statistical method described by Panse and Sukhatme (1967) was followed for analysis and interpretation of the experimental results.

\section{Results and Discussion}

There was no significant change in total soluble solids of nectar prepared from fresh and stored pulp. TSS increased with the increase in storage period (Table 1). The maximum TSS (15.42\%) was recorded on $120^{\text {th }}$ day of storage, whereas, it was minimum $(15.00 \%)$ on 0 day of storage. The interaction between storage conditions and storage periods was found non-significant.

The perusal of data in table 2 reveals that no significant variation in percent acidity was observed in nectar prepared from fresh and stored pulp and it varied between $0.38 \%$ and 0.41 per cent. No significant change was observed in acid content during storage and remained between 0.41 and 0.36 per cent. The interaction between treatments and storage periods was also found to be non-significant. TSS to acid ratio varied significantly in the nectar prepared from the pulp of different treatments (Table 3). The maximum TSS to acid ratio (40.3) was recorded in the nectar prepared from two months stored pulp at frozen temperature $\left(\mathrm{T}_{4}\right)$ and it was at par with 
the nectar prepared from fresh pulp $\left(\mathrm{T}_{1}\right)$, stored pulp at frozen temperature for four months $\left(\mathrm{T}_{5}\right)$ and stored pulp at refrigerated temperature for two months $\left(\mathrm{T}_{2}\right)$, whereas, the minimum (37.7) was recorded in nectar prepared from pulp stored at ambient room temperature for four months $\left(\mathrm{T}_{7}\right)$, which was at par with $\mathrm{T}_{6}$. A significant increase in the TSS to acid ratio was obtained with the increase in the storage period. It was 36.0 on initial day of storage and increased to 42.5 on $120^{\text {th }}$ day of storage, which was at par with $105^{\text {th }}$ day of storage. The interaction between treatments and storage periods was nonsignificant.

No significant difference was observed in total sugars of nectar prepared from fresh and stored pulp (Table 4), however, the total sugars varied from14.56to $14.76 \%$ in nectar prepared from pulp of different treatments. The total sugars content increased in nectar with the increase in storage period and it was minimum (14.18\%) on 0 day of storage, which increased to $14.97 \%$ on $120^{\text {th }}$ day of storage. There was no significant variation in sugar content of the nectar on $90^{\text {th }}$ to $120^{\text {th }}$ day of storage. The interaction between treatments and storage periods was non-significant.

The results reveal that the reducing sugars did not differ significantly in nectar prepared from fresh and stored pulp (Table 5). It varied between 11.07 and $11.44 \%$ in nectar prepared from the pulp of different treatments. The reducing sugars increased significantly with the increase in storage period and recorded minimum $(10.24 \%)$ on 0 day of storage, whereas, the maximum $(12.00 \%)$ was found on $120^{\text {th }}$ day of storage, which was at par with $105^{\text {th }}$ day of storage. The interaction between treatments and storage periods was found to be non-significant.
The non-reducing sugars decreased with the increase in storage period (Table 6) and the maximum $(3.94 \%)$ was recorded at initial days of storage, whereas, the minimum $(2.97 \%)$ was obtained on $105^{\text {th }}$ day of storage, which was at par with $90^{\text {th }}$ day of storage. However, the decrease was non-significant up to $30^{\text {th }}$ day of storage. The interaction between treatments and storage periods was found non-significant.

The average maximum (8.1) score was observed (Table 7) for the nectar prepared from pulp stored at frozen temperature for two months $\left(\mathrm{T}_{4}\right)$, which was at par with $\mathrm{T}_{1}$ and $\mathrm{T}_{5}$ (8.0), whereas, the minimum (6.8) score was given to the nectar prepared from pulp stored at ambient room temperature for four months $\left(\mathrm{T}_{7}\right)$. The overall acceptability score progressively decreased with the increase in storage period. The minimum (7.1) score was obtained on $120^{\text {th }}$ day of storage. However, the nectar prepared from fresh and stored pulp remained acceptable up to $120^{\text {th }}$ day of storage at ambient room temperature.

The total soluble solids remained unchanged in nectar prepared from fresh and stored pulp of plum. It indicates that stored pulp was similar to fresh pulp. Hence, the pulp can easily be stored for utilization in off season. An increasing trend was observed in total soluble solids with the increase in storage period. The increase in TSS might be due to the conversion of protopectin into water soluble pectin during storage. Similar trend was observed in TSS in nectar prepared from custard apple and blended nectar from papaya and banana during 60 days of storage by Shrivastava et al., (2013) and Thakre and Jain (2013), respectively. 
Table.1 Changes in total soluble solid (\%) of nectar prepared from fresh and Stored pulp during storage

\begin{tabular}{|c|c|c|c|c|c|c|c|c|c|c|}
\hline \multirow{2}{*}{ Treatment } & \multicolumn{10}{|c|}{ Storage period (days) } \\
\cline { 2 - 11 } & $\mathbf{0}$ & $\mathbf{1 5}$ & $\mathbf{3 0}$ & $\mathbf{4 5}$ & $\mathbf{6 0}$ & $\mathbf{7 5}$ & $\mathbf{9 0}$ & $\mathbf{1 0 5}$ & $\mathbf{1 2 0}$ & Mean \\
\hline $\mathbf{T}_{\mathbf{1}}$ & 15.00 & 15.00 & 15.15 & 15.20 & 15.28 & 15.30 & 15.33 & 15.35 & 15.36 & $\mathbf{1 5 . 2 2}$ \\
\hline $\mathbf{T}_{\mathbf{2}}$ & 15.00 & 15.10 & 15.18 & 15.21 & 15.28 & 15.34 & 15.40 & 15.40 & 15.40 & $\mathbf{1 5 . 2 6}$ \\
\hline $\mathbf{T}_{\mathbf{3}}$ & 15.00 & 15.15 & 15.21 & 15.25 & 15.33 & 15.38 & 15.40 & 15.41 & 15.43 & $\mathbf{1 5 . 2 8}$ \\
\hline $\mathbf{T}_{\mathbf{4}}$ & 15.00 & 15.10 & 15.13 & 15.18 & 15.25 & 15.28 & 15.35 & 15.36 & 15.38 & $\mathbf{1 5 . 2 2}$ \\
\hline $\mathbf{T}_{\mathbf{5}}$ & 15.00 & 15.10 & 15.18 & 15.23 & 15.25 & 15.33 & 15.38 & 15.38 & 15.40 & $\mathbf{1 5 . 2 5}$ \\
\hline $\mathbf{T}_{\mathbf{6}}$ & 15.00 & 15.20 & 15.28 & 15.30 & 15.38 & 15.38 & 15.43 & 15.45 & 15.45 & $\mathbf{1 5 . 3 2}$ \\
\hline $\mathbf{T}_{\mathbf{7}}$ & 15.00 & 15.20 & 15.35 & 15.35 & 15.40 & 15.43 & 15.45 & 15.48 & 15.50 & $\mathbf{1 5 . 3 5}$ \\
\hline Mean & $\mathbf{1 5 . 0 0}$ & $\mathbf{1 5 . 1 2}$ & $\mathbf{1 5 . 2 1}$ & $\mathbf{1 5 . 2 5}$ & $\mathbf{1 5 . 3 1}$ & $\mathbf{1 5 . 3 5}$ & $\mathbf{1 5 . 3 9}$ & $\mathbf{1 5 . 4 0}$ & $\mathbf{1 5 . 4 2}$ & \\
\hline CD at 5\% & \multicolumn{10}{|c|}{ Treatment- NS Storage period - 0.07 T x SP - NS } \\
\hline
\end{tabular}

$\mathrm{T}_{1^{-}}$- Fresh pulp, $\mathrm{T}_{2^{-}}$Pulp stored at refrigerating temperature $\left(6 \pm 2^{\circ} \mathrm{C}\right)$ for two months, $\mathrm{T}_{3}-$ Pulp stored at refrigerating temperature $\left(6 \pm 2^{\circ} \mathrm{C}\right)$ for four months, $\mathrm{T}_{4}$ - Frozen pulp stored for two months $\left(-10 \pm 5^{\circ} \mathrm{C}\right), \mathrm{T}_{5}$ - Frozen pulp stored for four months $\left(-10 \pm 5^{\circ} \mathrm{C}\right), \mathrm{T}_{6}$ - Pulp stored at ambient temperature for two months, $\mathrm{T}_{7}$ - Pulp stored at ambient temperature for four months.

Table.2 Changes in acidity (\%) of nectar prepared from fresh and stored pulp during storage

\begin{tabular}{|c|c|c|c|c|c|c|c|c|c|c|}
\hline \multirow{2}{*}{ Treatment } & \multicolumn{10}{|c|}{ Storage period (days) } \\
\cline { 2 - 12 } & $\mathbf{0}$ & $\mathbf{1 5}$ & $\mathbf{3 0}$ & $\mathbf{4 5}$ & $\mathbf{6 0}$ & $\mathbf{7 5}$ & $\mathbf{9 0}$ & $\mathbf{1 0 5}$ & $\mathbf{1 2 0}$ & Mean \\
\hline $\mathrm{T} 1$ & 0.40 & 0.40 & 0.40 & 0.39 & 0.39 & 0.38 & 0.37 & 0.36 & 0.36 & $\mathbf{0 . 3 8}$ \\
\hline $\mathrm{T} 2$ & 0.41 & 0.40 & 0.40 & 0.39 & 0.39 & 0.38 & 0.37 & 0.36 & 0.36 & $\mathbf{0 . 3 8}$ \\
\hline $\mathrm{T} 3$ & 0.42 & 0.41 & 0.40 & 0.39 & 0.39 & 0.38 & 0.38 & 0.37 & 0.36 & $\mathbf{0 . 3 9}$ \\
\hline $\mathrm{T} 4$ & 0.40 & 0.40 & 0.39 & 0.39 & 0.38 & 0.38 & 0.37 & 0.36 & 0.36 & $\mathbf{0 . 3 8}$ \\
\hline $\mathrm{T} 5$ & 0.40 & 0.40 & 0.40 & 0.39 & 0.39 & 0.38 & 0.37 & 0.36 & 0.36 & $\mathbf{0 . 3 8}$ \\
\hline $\mathrm{T} 6$ & 0.43 & 0.42 & 0.41 & 0.41 & 0.40 & 0.40 & 0.39 & 0.38 & 0.38 & $\mathbf{0 . 4 0}$ \\
\hline $\mathrm{T} 7$ & 0.44 & 0.43 & 0.42 & 0.42 & 0.41 & 0.40 & 0.39 & 0.39 & 0.38 & $\mathbf{0 . 4 1}$ \\
\hline Mean & $\mathbf{0 . 4 1}$ & $\mathbf{0 . 4 1}$ & $\mathbf{0 . 4 0}$ & $\mathbf{0 . 4 0}$ & $\mathbf{0 . 3 9}$ & $\mathbf{0 . 3 9}$ & $\mathbf{0 . 3 8}$ & $\mathbf{0 . 3 7}$ & $\mathbf{0 . 3 6}$ & \\
\hline CD at 5\% & \multicolumn{10}{|c|}{ Treatment- NS Storage period - NS T x SP - NS } \\
\hline
\end{tabular}


Table.3 Changes in TSS to acid ratio of nectar prepared from fresh and Stored pulp during storage

\begin{tabular}{|c|c|c|c|c|c|c|c|c|c|c|}
\hline \multirow{2}{*}{ Treatment } & \multicolumn{10}{|c|}{ Storage period (days) } \\
\cline { 2 - 12 } & $\mathbf{0}$ & $\mathbf{1 5}$ & $\mathbf{3 0}$ & $\mathbf{4 5}$ & $\mathbf{6 0}$ & $\mathbf{7 5}$ & $\mathbf{9 0}$ & $\mathbf{1 0 5}$ & $\mathbf{1 2 0}$ & Mean \\
\hline T1 & 37.3 & 37.5 & 38.3 & 39.3 & 39.9 & 40.6 & 41.8 & 43.3 & 43.4 & $\mathbf{4 0 . 2}$ \\
\hline T2 & 36.2 & 37.4 & 38.1 & 39.0 & 39.9 & 40.4 & 41.8 & 43.0 & 43.0 & $\mathbf{3 9 . 8}$ \\
\hline T3 & 35.5 & 37.1 & 38.0 & 38.9 & 39.4 & 40.4 & 41.4 & 42.2 & 42.9 & $\mathbf{3 9 . 5}$ \\
\hline T4 & 37.3 & 37.9 & 38.9 & 39.7 & 40.2 & 40.7 & 42.0 & 42.9 & 43.3 & $\mathbf{4 0 . 3}$ \\
\hline T5 & 37.3 & 37.6 & 38.4 & 39.2 & 39.4 & 40.5 & 41.5 & 42.7 & 43.2 & $\mathbf{4 0 . 0}$ \\
\hline T6 & 34.7 & 35.9 & 36.9 & 37.2 & 38.3 & 38.6 & 40.0 & 40.6 & 40.6 & $\mathbf{3 8 . 1}$ \\
\hline T7 & 33.9 & 35.2 & 36.1 & 36.7 & 37.6 & 38.8 & 39.4 & 40.5 & 40.8 & $\mathbf{3 7 . 7}$ \\
\hline Mean & $\mathbf{3 6 . 0}$ & $\mathbf{3 6 . 9}$ & $\mathbf{3 7 . 8}$ & $\mathbf{3 8 . 6}$ & $\mathbf{3 9 . 2}$ & $\mathbf{4 0 . 0}$ & $\mathbf{4 1 . 1}$ & $\mathbf{4 2 . 2}$ & $\mathbf{4 2 . 5}$ & \\
\hline CD at 5\% & \multicolumn{10}{|c|}{ Treatment- 0.53 Storage period - 0.60 T X SP - NS } \\
\hline
\end{tabular}

Table.4 Changes in total sugars (\%) of nectar prepared from fresh and stored pulp during storage

\begin{tabular}{|c|c|c|c|c|c|c|c|c|c|c|}
\hline Treatment & \multicolumn{10}{|c|}{ Storage period (days) } \\
\hline & $\mathbf{0}$ & $\mathbf{1 5}$ & $\mathbf{3 0}$ & $\mathbf{4 5}$ & $\mathbf{6 0}$ & $\mathbf{7 5}$ & $\mathbf{9 0}$ & $\mathbf{1 0 5}$ & $\mathbf{1 2 0}$ & Mean \\
\hline $\mathbf{T}_{\mathbf{1}}$ & 14.10 & 14.10 & 14.23 & 14.39 & 14.65 & 14.78 & 14.90 & 14.94 & 14.94 & $\mathbf{1 4 . 5 6}$ \\
\hline $\mathbf{T}_{\mathbf{2}}$ & 14.15 & 14.21 & 14.29 & 14.45 & 14.73 & 14.81 & 14.93 & 14.95 & 14.95 & $\mathbf{1 4 . 6 1}$ \\
\hline $\mathbf{T}_{\mathbf{3}}$ & 14.20 & 14.27 & 14.31 & 14.55 & 14.73 & 14.84 & 14.95 & 14.97 & 14.97 & $\mathbf{1 4 . 6 4}$ \\
\hline $\mathbf{T}_{\mathbf{4}}$ & 14.10 & 14.19 & 14.23 & 14.41 & 14.67 & 14.76 & 14.89 & 14.94 & 14.94 & $\mathbf{1 4 . 5 7}$ \\
\hline $\mathbf{T}_{\mathbf{5}}$ & 14.10 & 14.24 & 14.29 & 14.47 & 14.71 & 14.81 & 14.92 & 14.95 & 14.95 & $\mathbf{1 4 . 6 0}$ \\
\hline $\mathbf{T}_{\mathbf{6}}$ & 14.28 & 14.36 & 14.57 & 14.61 & 14.79 & 14.87 & 14.96 & 14.98 & 14.98 & $\mathbf{1 4 . 7 1}$ \\
\hline $\mathbf{T}_{\mathbf{7}}$ & 14.33 & 14.42 & 14.64 & 14.73 & 14.81 & 14.89 & 14.96 & 15.02 & 15.02 & $\mathbf{1 4 . 7 6}$ \\
\hline Mean & $\mathbf{1 4 . 1 8}$ & $\mathbf{1 4 . 2 6}$ & $\mathbf{1 4 . 3 7}$ & $\mathbf{1 4 . 5 2}$ & $\mathbf{1 4 . 7 3}$ & $\mathbf{1 4 . 8 2}$ & $\mathbf{1 4 . 9 3}$ & $\mathbf{1 4 . 9 6}$ & $\mathbf{1 4 . 9 7}$ & \\
\hline CD at 5\% & \multicolumn{10}{|c|}{ Treatment- NS Storage period - 0.08 T X SP - NS } \\
\hline
\end{tabular}

Table.5 Changes in reducing sugars (\%) of nectar prepared from fresh and Stored pulp during storage

\begin{tabular}{|c|c|c|c|c|c|c|c|c|c|c|}
\hline \multirow{2}{*}{ Treatment } & \multicolumn{10}{|c|}{ Storage period (days) } \\
\cline { 2 - 12 } & $\mathbf{0}$ & $\mathbf{1 5}$ & $\mathbf{3 0}$ & $\mathbf{4 5}$ & $\mathbf{6 0}$ & $\mathbf{7 5}$ & $\mathbf{9 0}$ & $\mathbf{1 0 5}$ & $\mathbf{1 2 0}$ & Mean \\
\hline $\mathbf{T}_{\mathbf{1}}$ & 10.10 & 10.15 & 10.31 & 10.47 & 11.14 & 11.59 & 11.87 & 11.98 & 11.99 & $\mathbf{1 1 . 0 7}$ \\
\hline $\mathbf{T}_{\mathbf{2}}$ & 10.20 & 10.30 & 10.40 & 10.61 & 11.21 & 11.61 & 11.91 & 11.98 & 11.98 & $\mathbf{1 1 . 1 3}$ \\
\hline $\mathbf{T}_{\mathbf{3}}$ & 10.28 & 10.37 & 10.43 & 10.73 & 11.47 & 11.99 & 11.96 & 12.01 & 12.01 & $\mathbf{1 1 . 2 5}$ \\
\hline $\mathbf{T}_{\mathbf{4}}$ & 10.14 & 10.25 & 10.31 & 10.56 & 11.11 & 11.57 & 11.84 & 11.96 & 11.96 & $\mathbf{1 1 . 0 8}$ \\
\hline $\mathbf{T}_{\mathbf{5}}$ & 10.17 & 10.32 & 10.39 & 10.61 & 11.21 & 11.63 & 11.89 & 11.97 & 11.97 & $\mathbf{1 1 . 1 3}$ \\
\hline $\mathbf{T}_{\mathbf{6}}$ & 10.35 & 10.46 & 10.68 & 11.24 & 11.67 & 11.93 & 12.01 & 12.02 & 12.02 & $\mathbf{1 1 . 3 8}$ \\
\hline $\mathbf{T}_{\mathbf{7}}$ & 10.41 & 10.57 & 10.81 & 11.37 & 11.73 & 11.96 & 12.02 & 12.04 & 12.04 & $\mathbf{1 1 . 4 4}$ \\
\hline Mean & $\mathbf{1 0 . 2 4}$ & $\mathbf{1 0 . 3 5}$ & $\mathbf{1 0 . 4 8}$ & $\mathbf{1 0 . 8 0}$ & $\mathbf{1 1 . 3 6}$ & $\mathbf{1 1 . 7 5}$ & $\mathbf{1 1 . 9 3}$ & $\mathbf{1 1 . 9 9}$ & $\mathbf{1 2 . 0 0}$ & \\
\hline CD at 5\% & \multicolumn{10}{|c|}{ Treatment- NS Storage period - 0.06 T X SP - NS } \\
\hline
\end{tabular}


Table.6 Changes in non-reducing sugars (\%) of nectar prepared from fresh and Stored pulp during storage

\begin{tabular}{|c|c|c|c|c|c|c|c|c|c|c|}
\hline \multirow{2}{*}{ Treatment } & \multicolumn{10}{|c|}{ Storage period (days) } \\
\cline { 2 - 12 } & $\mathbf{0}$ & $\mathbf{1 5}$ & $\mathbf{3 0}$ & $\mathbf{4 5}$ & $\mathbf{6 0}$ & $\mathbf{7 5}$ & $\mathbf{9 0}$ & $\mathbf{1 0 5}$ & $\mathbf{1 2 0}$ & Mean \\
\hline $\mathbf{T}_{\mathbf{1}}$ & 4.00 & 3.95 & 3.92 & 3.92 & 3.51 & 3.19 & 3.03 & 2.96 & 2.96 & $\mathbf{3 . 4 9}$ \\
\hline $\mathbf{T}_{\mathbf{2}}$ & 3.95 & 3.91 & 3.89 & 3.84 & 3.52 & 3.20 & 3.02 & 2.97 & 2.97 & $\mathbf{3 . 4 7}$ \\
\hline $\mathbf{T}_{\mathbf{3}}$ & 3.92 & 3.90 & 3.87 & 3.83 & 3.26 & 3.10 & 2.98 & 2.96 & 2.97 & $\mathbf{3 . 4 2}$ \\
\hline $\mathbf{T}_{\mathbf{4}}$ & 3.96 & 3.94 & 3.92 & 3.85 & 3.53 & 3.19 & 3.05 & 2.97 & 2.98 & $\mathbf{3 . 4 9}$ \\
\hline $\mathbf{T}_{\mathbf{5}}$ & 3.93 & 3.92 & 3.90 & 3.86 & 3.50 & 3.18 & 3.03 & 2.98 & 2.98 & $\mathbf{3 . 4 7}$ \\
\hline $\mathbf{T}_{\mathbf{6}}$ & 3.93 & 3.91 & 3.89 & 3.37 & 3.12 & 2.94 & 2.95 & 2.96 & 2.96 & $\mathbf{3 . 3 4}$ \\
\hline $\mathbf{T}_{\mathbf{7}}$ & 3.92 & 3.90 & 3.90 & 3.39 & 3.11 & 2.91 & 2.91 & 2.95 & 2.96 & $\mathbf{3 . 3 3}$ \\
\hline Mean & $\mathbf{3 . 9 4}$ & $\mathbf{3 . 9 2}$ & $\mathbf{3 . 9 0}$ & $\mathbf{3 . 7 2}$ & $\mathbf{3 . 3 6}$ & $\mathbf{3 . 1 0}$ & $\mathbf{3 . 0 0}$ & $\mathbf{2 . 9 7}$ & $\mathbf{2 . 9 7}$ & \\
\hline CD at 5\% & \multicolumn{10}{|c|}{ Treatment- NS Storage period - 0.06 T XP - NS } \\
\hline
\end{tabular}

Table.7 Changes in overall acceptability of organoleptic scores (out of 9) in nectar prepared from fresh and stored pulp during storage

\begin{tabular}{|c|c|c|c|c|c|c|c|c|c|c|}
\hline \multirow{2}{*}{ Treatment } & \multicolumn{10}{|c|}{ Storage period (days) } \\
\cline { 2 - 12 } & $\mathbf{0}$ & $\mathbf{1 5}$ & $\mathbf{3 0}$ & $\mathbf{4 5}$ & $\mathbf{6 0}$ & $\mathbf{7 5}$ & $\mathbf{9 0}$ & $\mathbf{1 0 5}$ & $\mathbf{1 2 0}$ & Mean \\
\hline $\mathbf{T}_{\mathbf{1}}$ & 8.8 & 8.7 & 8.4 & 8.2 & 7.9 & 7.8 & 7.6 & 7.4 & 7.3 & $\mathbf{8 . 0}$ \\
\hline $\mathbf{T}_{\mathbf{2}}$ & 8.6 & 8.4 & 8.3 & 8.2 & 8.0 & 7.8 & 7.5 & 7.4 & 7.2 & $\mathbf{7 . 9}$ \\
\hline $\mathbf{T}_{\mathbf{3}}$ & 8.5 & 8.3 & 8.1 & 8.0 & 7.9 & 7.7 & 7.4 & 7.3 & 7.2 & $\mathbf{7 . 8}$ \\
\hline $\mathbf{T}_{\mathbf{4}}$ & 8.7 & 8.5 & 8.4 & 8.3 & 8.2 & 8.0 & 7.8 & 7.7 & 7.5 & $\mathbf{8 . 1}$ \\
\hline $\mathbf{T}_{\mathbf{5}}$ & 8.6 & 8.4 & 8.3 & 8.2 & 8.1 & 7.8 & 7.6 & 7.4 & 7.3 & $\mathbf{8 . 0}$ \\
\hline $\mathbf{T}_{\mathbf{6}}$ & 7.7 & 7.4 & 7.3 & 7.2 & 7.2 & 7.1 & 7.0 & 6.9 & 6.6 & $\mathbf{7 . 1}$ \\
\hline $\mathbf{T}_{\mathbf{7}}$ & 7.3 & 7.2 & 7.1 & 7.0 & 6.8 & 6.8 & 6.6 & 6.5 & 6.3 & $\mathbf{6 . 8}$ \\
\hline Mean & $\mathbf{8 . 3}$ & $\mathbf{8 . 1}$ & $\mathbf{8 . 0}$ & $\mathbf{7 . 9}$ & $\mathbf{7 . 7}$ & $\mathbf{7 . 6}$ & $\mathbf{7 . 4}$ & $\mathbf{7 . 2}$ & $\mathbf{7 . 1}$ & \\
\hline CD at 5\% & \multicolumn{9}{|c|}{ Treatment- 0.14 Storage period - 0.16 T x SP - NS } \\
\hline
\end{tabular}

The acid content in nectar prepared from fresh and stored pulp did not differ significantly (Table 2). Similarly, no variation in acid content was recorded throughout the storage period of 120 days. Thakre and Jain (2013) also reported a non-significant decrease in acidity of blended nectar of papaya and banana during 60 days of storage. Contrary to these results, Kumari and Sandal (2011) noticed a significant increase in acidity of squash and RTS beverage prepared from local mango during storage for 100 days at ambient temperature. Similar trend was observed by Shrivastava et al., (2013) in custard apple nectar during 60 days of storage at ambient temperature. In the present investigation, the maximum TSS to acid ratio was noticed in nectar prepared pulp stored at frozen temperature for four months followed by fresh pulp and the minimum TSS to acid ratio was found in nectar prepared from pulp stored at ambient room temperature for four months. The TSS to acid ratio increased significantly with the increase in storage period and its value ranged from 36.0 to 42.5 in nectar from 0 day to end of storage period (Table 3 ). The increase in TSS to acid ratio was due to increase in TSS and decrease in acid contents during storage. Contrary to this, Shrivastava et al., (2013) in custard apple nectar, reported decrease in TSS to acid ratio with the increase in storage period. 
The results reveal that no variation in total sugars content was found in nectar prepared by various treatments using fresh and stored pulp of plum (Table 4). A gradual increasing trend in total sugars was noticed with the increase in storage period from $30^{\text {th }}$ to $90^{\text {th }}$ day of storage and thereafter no significant variation was observed.

A similar trend was observed by Thakre and Jain (2013) in blended nectar of papaya and banana and Saravanan et al., (2004) in papaya nectar.

In the present study, no significant variation was noticed in reducing sugars in nectar prepared from fresh and stored pulp among different treatments, but it increased significantly with the increase in storage period. Increase in reducing sugars might be due to hydrolysis of sugar by acid, which might have resulted in degradation of disaccharides to monosaccharides. Similar findings were reported by Shrivastava et al., (2013) in custard apple nectar during storage of 60 days at ambient temperature. Thakre and Jain (2013) also reported increasing trend in reducing sugars during storage in blended nectar of papaya and custard apple for 60 days.

No significant variation in non-reducing sugar was observed in nectar prepared from fresh and stored pulp at different temperature. However, with the increase in storage period, there was a significant and progressive decrease in non-reducing sugar (Table 6). The reduction in non-reducing sugar might be due to conversion of non-reducing sugar into reducing sugars during storage. The Similar trends were also reported in papaya (Saravanan et al., 2004) and guava nectar (Choudhary, 2004). Kumari and Sandal (2011) also reported a similar trend in squash and RTS beverage of local mango stored for 100 days.
The nectar prepared from all the treatments using fresh and stored pulp remained acceptable up to $120^{\text {th }}$ day of storage at ambient room temperature because each of these scored more than 6.0 overall acceptability score (Table 7). However, the nectar prepared from pulp stored at frozen temperature for two months scored highest acceptability, which was comparable with nectar prepared from fresh pulp and pulp stored at frozen temperature for four months and the least was observed in nectar prepared from pulp stored at ambient room temperature for four months. Acceptability scores of nectar decreased during storage but remained in the acceptable range up to $120^{\text {th }}$ day of storage at room temperature. Hayati (1987) also observed that ready to serve beverage prepared from stored guava pulp treated with $0.1 \%$ potassium metabisulphite (KMS) and packed in glass containers or PVC (transparent) containers kept at low temperature was found comparable with ready to serve beverage prepared from fresh pulp due to its better colour, taste and flavour. Shivani et al., (2010) also reported that the jamun jam was found acceptable even after 3 months of storage at ambient temperature, however, the overall acceptability of jam decreased significantly with the advancement in storage period. Similar trend was noticed by Khan et al., (2012) in case of strawberry jam stored in sterilized glass jars for 60 days.

\section{References}

A.O.A.C. 1990. Official Methods of Analysis. $15^{\text {th }}$ Edn.Association of Official Analytical Chemist, Washington, D.C.

Anonymous 2004. Plum. In: The Columbia Electronic Encyclopedia, $6^{\text {th }}$ Ed. Columbia University Press, New York (http://www.columbia.edu/cu/cup/).

Anonymous 2011. Food and Agriculture Organization Year Book (http:/faostat3.fao.org.)

Choudhary, M. 2004. Evaluation of guava 
(Psidium guajava L.) varieties for processing into nectar and ready to serve beverage. M. Sc. (Ag.) Thesis. I.G.K.V., Raipur (CG.)

Durrani, Y., Ayub, M., Muhammad, A. and Asad, A. 2010. Physicochemical response of apple pulp to chemical preservatives and antioxidant during storage. International Journal of Food Safety, 12: 20-28.

Gothwal, P.P., Satpute, D.B., Manan, J.K. and Velu, V. 1998. Preparation and storage of some processed products from some varieties of plum (Santa Rosa, Mariposa and Early Transparent Gage) grown in hill region of Uttar Pradesh. Indian Food Packer, 52(3): 21-27.

Hayati, R. 1987. Studies on the preservation of pulp from guava fruit (Psidium guajava L.). M.Sc. thesis submitted to CCS HAU, Hisar.

Hulme, A.C. and Narain, R. 1931. The ferrycynide method for determination of reducing sugars. A modification of Hegedom-Jenson Hanes Technique. Biochemistry Journal, 25: 1051-1061.

Jain, P.K., Jain, P. and Nema, P.K. 2011. Quality of guava and papaya fruit pulp as influenced by blending ratio and storage period. American J. Food Technology, 6(6): 507.

Khan, R.U., Afridi, S.R., Ilyas, M., Sohail, M. and Abid, H. 2012. Development of strawberry jam and its quality evaluation during storage. Pakistan Journal of Biochemistry and Molecular Biology, 45(1): 23-25.

Kumari, A. and Sandal, A. 2011. Quality evaluation of products prepared from local mango. Indian Journal of Agriculture Biochemistry, 24(2): 131-135.

Navarro, M.L., Perez-Gago, M.B. and Rio,
M.A.D. 2005. Effect of hydroxylpropyl methylcellulose-beeswax edible composite coatings on Angeleno plum quality during storage. Acta Hort., 682: 1089-1096.

Panse, V.G. and Sukatme, P.V. 1967. Statistical Methods for Agricultural Workers. Indian Council of Agricultural Research, New Delhi, p. 155.

Ranganna, S. 1977. Manual of analysis of Fruits and Vegetable Products. Tata McGraw Hill Publishing Co. Ltd., New Delhi.

Sakhale, B.K., Pawar, V.N. and Ranveer, R.C. 2012. Studies on effect of chemical preservative on keeping quality of Kesar mango pulp. Open Access Scientific Reports. 1(3). http://dx.doi.org/10.4172/ scientificreports. 184 .

Saravanan, K., Godara, R.K., Goyal, R.K. and Sharma, R.K. 2004. Standardization of recipe for papaya nectar and its storage. Haryana Journal of Horticultural Sciences, 33(3 \& 4): 204-206.

Shivani, Gehlot, R., Singh, R. and Siddiqui, S. 2010. Standardization of processing technology for Jamun (Syzygium cuminii L.) jam and chutney. Haryana Journal of Horticultural Sciences, 39(3\&4): 263-265.

Shrivastava, R., Dubey, S., Dwivedi, A.P., Pandey, C.S. and Banafar, R.N.S. 2013. Effect of recipe treatment and storage period on biochemical composition of custard apple (Annona squamosa L.) nectar. Progressive Horticulture, 45(1): 110-114.

Thakre, M. and Jain, V. 2013. Storage study of blended nectar of papaya and banana under different storage conditions. Progressive Horticulture, 45(1): 100-103.

\section{How to cite this article:}

Kundu, S.S., R.K. Sharma and Goyal, R.K. 2017. Quality Status of Nectar Preparation from Fresh and Stored Pulp of Plum cv. Satluj Purple. Int.J.Curr.Microbiol.App.Sci. 6(6): 17981805. doi: https://doi.org/10.20546/ijcmas.2017.606.209 